\title{
Rapidly Developing Cataract in Young Adult Patients: Always a Matter for Further Evaluation
}

\author{
Naresh K. Midha ${ }^{1}$, Mahendra Kumar Garg ${ }^{1}$, Deepak Kumar ${ }^{1}$, Durga Shankar Meena ${ }^{1}$, Gopal K. Bohra ${ }^{1}$
}

1. Medicine, All India Institute of Medical Sciences, Jodhpur, IND

Corresponding author: Naresh K. Midha, midha.naresh@gmail.com

\begin{abstract}
A cataract in the young age group is uncommon and it is usually secondary to eye trauma, intraocular inflammation, uncontrolled diabetes mellitus, and hypoparathyroidism. We report a case of a rapidly developing cataract over two years in a 21-year-old female with extensive intracranial calcification due to primary hypoparathyroidism.
\end{abstract}

Chronic hypocalcemia due to underlying hypoparathyroidism results in cataract. Extensive bilateral intracranial calcification involving basal ganglia and white matter has been rarely reported in the literature. It occurs due to the chronic deposition of calcium-phosphorus complexes.

We would like to highlight that cataract in young patients is always a matter for further evaluation. Clinicians and ophthalmologists should be aware of hypoparathyroidism as a cause of bilateral cataracts. Early diagnosis of primary hypoparathyroidism can save patients from many complications.

Categories: Endocrinology/Diabetes/Metabolism, Internal Medicine, Ophthalmology Keywords: hypoparathyroidism, cataract, intracranial calcification

\section{Introduction}

Cataract is the main cause of blindness in developing countries. Cataract in the young adult age group is less common and it is usually secondary to eye trauma, intraocular inflammation, diabetes mellitus, inborn errors of metabolism, chronic hypocalcemia, and prolonged use of steroids. High myopia, prolonged dehydration, allergic dermatitis, and chronic uveitis are also mentioned risk factors for the development of cataract at a young age [1].

Review began 07/26/2021 Review ended 08/16/2021 Published 08/19/2021

\section{() Copyright 2021}

Midha et al. This is an open access article distributed under the terms of the Creative Commons Attribution License CC-BY 4.0., which permits unrestricted use, distribution, and reproduction in any medium, provided the original author and source are credited.
Young adult cataract due to hypocalcemia with underlying primary hypoparathyroidism is a rare condition. Hypocalcemia is characterized by muscle cramps, tetany, fatigue, paraesthesia, headache, and abdominal pain. Seizures and cardiac arrhythmias are life-threatening emergencies associated with hypocalcemia [2].

Ophthalmic involvements in hypoparathyroidism are well established and include papilledema and early cataract. Cataracts associated with primary hypoparathyroidism are mostly cortical and develop slowly while in secondary hypoparathyroidism, posterior subscapular cataract is more common, and it evolves rapidly [3].

We report a case of rapidly developing cataract over two years in a 21-year-old female due to primary hypoparathyroidism. Awareness of this rare complication can help in early diagnosis and further evaluation of cataract at the young age group

\section{Case Presentation}

A 21-year-old unmarried female presented to our outpatient department with complaints of muscular spasms from six years and difficulty in the vision of the right eye for the last year. The muscular spasms usually started from the legs and progressed to all extremities, worsened by cold. On further evaluation, she reported complaints of paraesthesia (tingling and pricking sensations) in limbs, around the mouth and difficulty in speech. The patient reported episodes of vertigo with a single episode of fall. She had no complaints of seizures in the past with no complaints of extrapyramidal symptoms.

The patient had a history of cataract surgery in the left eye two years ago. There was no history of comorbidities and any neck surgery like thyroidectomy. She denied any arthralgia, photosensitivity and oral ulcerations. Family history was also insignificant.

On examination, her vitals were within normal range. Neurological examination revealed a positive Chvostek and Trousseau's sign. There was no nystagmus, any abnormal movements or gait abnormality. Cardiovascular, respiratory, and abdominal examinations were unremarkable. Ophthalmological examination revealed a mature cataract in the right eye (Figure 1). 


\section{Cureus}

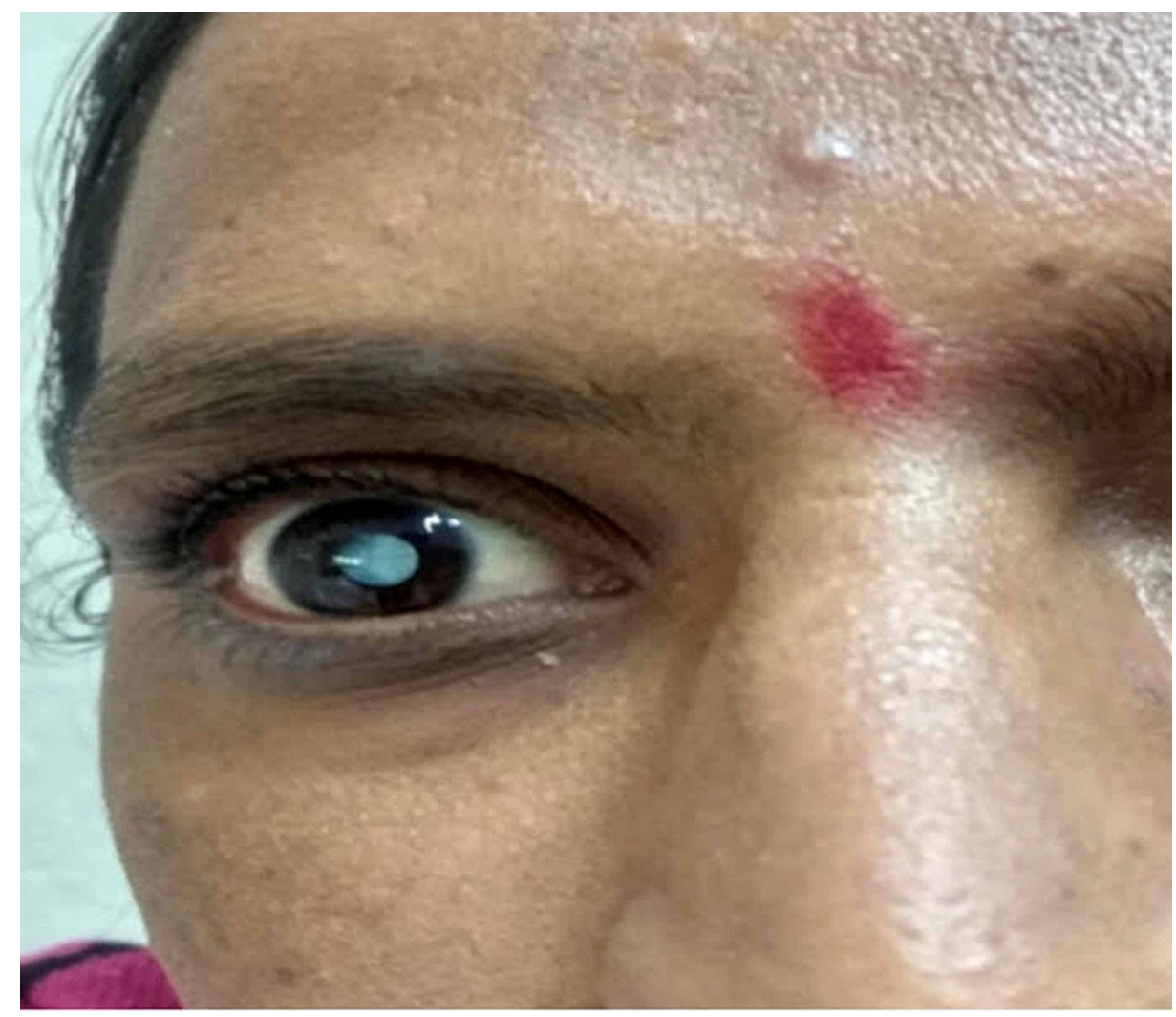

FIGURE 1: A mature cataract of right eye

Serum calcium was $4.81 \mathrm{mg} / \mathrm{dL}$ (normal range $8.8-10.6 \mathrm{mg} / \mathrm{dL}$ ), intact parathyroid hormone (PTH) $3.4 \mathrm{pg} / \mathrm{mL}$ (normal range $18.5-88.0 \mathrm{pg} / \mathrm{mL}$ ), serum phosphate $7.90 \mathrm{mg} / \mathrm{dL}$ (normal range $2.5-4.5 \mathrm{mg} / \mathrm{dL}$ ) with normal kidney functions. Lab results are shown in Table 1.

\begin{tabular}{|c|c|c|}
\hline Parameters & Value & Normal Range \\
\hline Serum calcium & $4.81 \mathrm{mg} / \mathrm{dL}$ & 8.8-10.6 mg/dL \\
\hline Serum phosphorus & $7.90 \mathrm{mg} / \mathrm{dL}$ & $2.5-4.5 \mathrm{mg} / \mathrm{dL}$ \\
\hline Serum sodium & $137 \mathrm{mEq} / \mathrm{L}$ & 135-145 mEq/L \\
\hline Serum potassium & $4.2 \mathrm{mEq} / \mathrm{L}$ & 3.5-5.0 mEq/L \\
\hline Serum 25 hydroxyl- vitamin D & $56.6 \mathrm{ng} / \mathrm{ml}$ & $30-100 \mathrm{ng} / \mathrm{ml}$ \\
\hline Parathyroid hormone & $3.4 \mathrm{pg} / \mathrm{mL}$ & $18.5-88.0 \mathrm{pg} / \mathrm{mL}$ \\
\hline Serum creatinine & $0.68 \mathrm{mg} / \mathrm{dL}$ & $0.51-1.2 \mathrm{mg} / \mathrm{dL}$ \\
\hline Serum albumin & $4.48 \mathrm{gm} / \mathrm{dL}$ & $3.5-5.2 \mathrm{~g} / \mathrm{dL}$ \\
\hline Alkaline phosphatase & $84 \mathrm{U} / \mathrm{L}$ & 30-120 U/L \\
\hline Hemoglobin & $10.7 \mathrm{gm} / \mathrm{dL}$ & 13-17 gm/dl \\
\hline Total leucocyte count & 5700 /cumm & 4000-10000/cumm \\
\hline Fasting blood glucose & $91 \mathrm{mg} / \mathrm{dL}$ & $80-100 \mathrm{mg} / \mathrm{dL}$ \\
\hline Thyroid-Stimulating Hormone & $2.27 \mathrm{mU} / \mathrm{L}$ & $0.4-4.2 \mathrm{mU} / \mathrm{L}$ \\
\hline
\end{tabular}

\section{TABLE 1: Biochemical and hematological investigations}




\section{Cureus}

A non-contrast computed tomography scan of the head was suggestive of bilateral extensive intracranial calcification in the caudate, thalamus, lentiform nucleus and corona radiata (Figure 2).

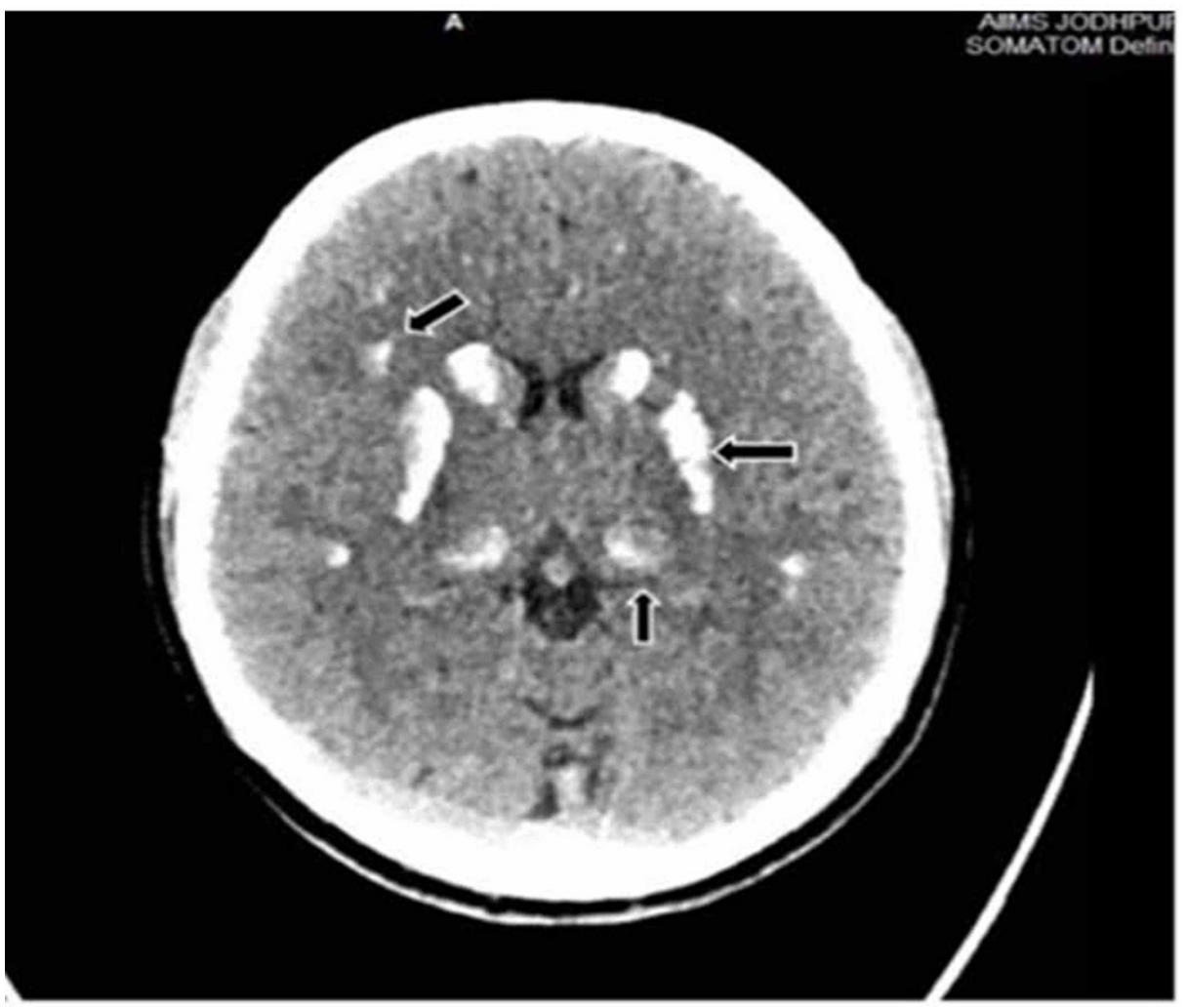

FIGURE 2: Non-contrast computed tomography Head showing large foci of parenchymal calcifications seen in bilateral putamen, thalami and grey-white matter junctions in bilateral frontal and parietal lobes. (Arrowed- Right frontal, left putamen and thalamus)

Based on these biochemical laboratory reports and radiological findings, the diagnosis was made as primary hypoparathyroidism with cataract and extensive intracranial calcification. The patient was started on oral calcium and active vitamin D, following which she developed significant improvement in her symptoms. Serum calcium level raised to normal range and muscular spasms were subsided. The patient was referred to the department of ophthalmology for surgical management of right eye cataract.

\section{Discussion}

Clinical presentation of hypoparathyroidism varies depending on the duration of hypocalcemia. Muscular cramps, tetany, paraesthesia, cardiac arrhythmias, altered mental status and seizures are usually acute manifestations. Cataract, basal ganglia calcifications, dilated cardiomyopathy, dementia and cerebellar dysfunction are chronic manifestations [4].

Cataract in young patients is usually secondary to eye trauma, uncontrolled diabetes, galactosemia, hypothyroidism, inborn error of copper metabolism and chronic hypocalcemia [5]. Cataract is a well-known complication of hypoparathyroidism. The progression of cataract is usually slow in patients with primary hypoparathyroidism while cataracts due to secondary hypoparathyroidism develop rapidly. Pathogenesis of cataract in hypoparathyroidism is proposed as membrane damage due to low calcium levels in the aqueous humour [6].

Extensive intracranial calcification is an occasional complication of hypoparathyroidism. Factors that predispose this brain calcification have not been completely elucidated. Prolonged hypocalcemia and hyperphosphatemia promote the deposition of calcium-phosphorus complexes in brain parenchymal tissue. Increased expression of osteogenesis-related molecules like osteonectin/osteopontin in the caudate nucleus and grey matter could favour metastatic calcification in hypoparathyroidism $[7,8]$.

Auto-immune hypoparathyroidism and genetic causes are important etiologies of primary

hypoparathyroidism [9]. However, anti-calcium sensing receptor (CaSR) antibodies and genetic testing for 
Glial Cell Missing-2 (GCM2) or CaSR genetic mutations could not be done due to non-availability of these testing facilities in our institute and economic constraints, thus these causes could not be excluded.

On review of the literature, we found various case reports of hypoparathyroidism with cataract or basal ganglia calcification. Goswami et al. [10] concluded in their study that 50\% of patients of idiopathic hypoparathyroidism had basal ganglia calcification with cataract, but there are very few reports of cataract along with intracranial calcification in primary hypoparathyroidism (Table 2).

\begin{tabular}{|c|c|c|c|}
\hline $\begin{array}{l}\text { Authors/ } \\
\text { reference no }\end{array}$ & $\begin{array}{l}\text { Patient } \\
\text { profile }\end{array}$ & $\begin{array}{l}\text { Duration of } \\
\text { disease }\end{array}$ & Remarks \\
\hline Xuan Liao et al. ${ }^{[3]}$ & $\begin{array}{l}37 \\
\text { years } / \text { male }\end{array}$ & 11 years & Bilateral cataract with seizures, Brain imaging is not mentioned \\
\hline Ramen C. Basak $^{[8]}$ & $\begin{array}{l}40 \\
\text { years } / \text { male }\end{array}$ & $\begin{array}{l}\text { Acute onset } \\
\text { seizures }\end{array}$ & Bilateral calcification in thalamus, dentate nuclei, putamen and cerebellum \\
\hline $\begin{array}{l}\text { Khalil Ahmed et al. } \\
\text { [11] }\end{array}$ & $\begin{array}{l}20 \\
\text { years/female }\end{array}$ & 3 years & Bilateral cataract with alopecia \\
\hline $\begin{array}{l}\text { Moushumi Lodh et } \\
\text { al. [12] }\end{array}$ & $\begin{array}{l}30 \\
\text { years/female }\end{array}$ & 6 years & Basal ganglia calcification with seizures \\
\hline $\begin{array}{l}\text { Ko Harada et al. } \\
\text { [13] }\end{array}$ & $\begin{array}{l}70 \\
\text { years/male }\end{array}$ & $\begin{array}{l}\text { Acute onset } \\
\text { hemiparesis }\end{array}$ & $\begin{array}{l}\text { Bilateral calcifications in basal ganglia, and cerebellum with acute cerebral } \\
\text { infarct }\end{array}$ \\
\hline Zhou YY et al. ${ }^{[14]}$ & $\begin{array}{l}62 \\
\text { years } / \text { male }\end{array}$ & 10 years & $\begin{array}{l}\text { Bilateral calcification in basal ganglia and cerebellum, presented with } \\
\text { tetany and speech difficulty }\end{array}$ \\
\hline
\end{tabular}

\section{TABLE 2: Review of literature for cataract and brain calcification in hypoparathyroidism}

In our patient, there was a right eye cataract and bilateral extensive intracranial calcification with a history of cataract surgery of the left eye two years back. If this patient was subjected to further evaluation of cataract at such a young age, perhaps she could have been prevented from getting cataract in the other eye.

\section{Conclusions}

We would like to highlight that cataract in young patients is always a matter for further evaluation. Clinicians and ophthalmologists should be aware of hypoparathyroidism as a cause of bilateral cataract. Early diagnosis of primary hypoparathyroidism can save patients from many complications.

\section{Additional Information \\ Disclosures}

Human subjects: Consent was obtained or waived by all participants in this study. Conflicts of interest: In compliance with the ICMJE uniform disclosure form, all authors declare the following: Payment/services info: All authors have declared that no financial support was received from any organization for the submitted work. Financial relationships: All authors have declared that they have no financial relationships at present or within the previous three years with any organizations that might have an interest in the submitted work. Other relationships: All authors have declared that there are no other relationships or activities that could appear to have influenced the submitted work.

\section{Acknowledgements}

We are thankful to Dr. Manish Sharma, consultant radiologist Apex Multi-Specialty Hospital Jaipur, India for his contribution to the description of CT imaging.

\section{References}

1. Praveen MR, Shah GD, Vasavada AR, Mehta PG, Gilbert C, Bhagat G: A study to explore the risk factors for the early onset of cataract in India. Eye (Lond). 2010, 24:686-94. 10.1038/eye.2009.137

2. Duval M, Bach K, Masson D, Guimard C, Le Conte P, Trewick D: Is severe hypocalcemia immediately lifethreatening?. Endocr Connect. 2018, 7:1067-74. 10.1530/EC-18-0267

3. Liao X, Huang X, Lan C, Li J, Tan Q: Characteristic cataract associated with idiopathic hypoparathyroidism. J Clin Exp Ophthalmol. 2016, 7:588. 10.4172/2155-9570.1000588

4. Lopes MP, Kliemann BS, Bini IB, et al.: Hypoparathyroidism and pseudohypoparathyroidism: etiology, 


\section{Cureus}

laboratory features and complications. Arch Endocrinol Metab. 2016, 60:532-6. 10.1590/2359-

3997000000221

5. Gupta VB, Rajagopala M, Ravishankar B: Etiopathogenesis of cataract: an appraisal. Indian J Ophthalmol. 2014, 62:103-10. 10.4103/0301-4738.121141

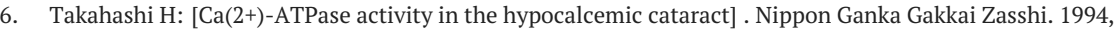
98:142-9.

7. Goswami R, Millo T, Mishra S, et al.: Expression of osteogenic molecules in the caudate nucleus and gray matter and their potential relevance for basal ganglia calcification in hypoparathyroidism. J Clin Endocrino Metab. 2014, 99:1741-8. 10.1210/jc.2013-3863

8. Basak RC: A case report of basal ganglia calcification - a rare finding of hypoparathyroidism . Oman Med J. 2009, 24:220-2. 10.5001/omj.2009.44

9. Khan AA, Koch CA, Van Uum S, et al.: Standards of care for hypoparathyroidism in adults: a Canadian and International Consensus. Eur J Endocrinol. 2019, 180:1-22. 10.1530/EJE-18-0609

10. Goswami R, Sharma R, Sreenivas V, Gupta N, Ganapathy A, Das S: Prevalence and progression of basal ganglia calcification and its pathogenic mechanism in patients with idiopathic hypoparathyroidism. Clin Endocrinol (Oxf). 2012, 77:200-6. 10.1111/j.1365-2265.2012.04353.x

11. Ahmed K, Rasool IA, Haider N, Ullah H, Usmani A: A rapidly developing cataract in idiopathic hypoparathyroidism: a case report. J Postgrad Med Inst. 2015, 29:52-4.

12. Moushumi L, Rajarshi M: Primary hypoparathyroidism misdiagnosed as epilepsy - a case report: seizures, hypocalcemia and cerebral calcification. EJIFCC. 2014, 25:195-8.

13. Harada K, Fujikawa T: Intracranial calcification due to hypoparathyroidism. Am J Med. 2018, 131:e253-4. 10.1016/j.amjmed.2017.12.030

14. Zhou YY, Yang Y, Qiu HM: Hypoparathyroidism with Fahr's syndrome: a case report and review of the literature. World J Clin Cases. 2019, 7:3662-70. 10.12998/wjcc.v7.i21.3662 